Review: Marine Algal Vegetation of Iceland

Author(s): A. D. Cotton

Review by: A. D. Cotton

Source: Journal of Ecology, Vol. 1, No. 2 (Jun., 1913), pp. 137-138

Published by: British Ecological Society

Stable URL: http://www.jstor.org/stable/2255686

Accessed: 08-05-2016 18:57 UTC

Your use of the JSTOR archive indicates your acceptance of the Terms \& Conditions of Use, available at

http://about.jstor.org/terms

JSTOR is a not-for-profit service that helps scholars, researchers, and students discover, use, and build upon a wide range of content in a trusted digital archive. We use information technology and tools to increase productivity and facilitate new forms of scholarship. For more information about JSTOR, please contact support@jstor.org.

Wiley, British Ecological Society are collaborating with JSTOR to digitize, preserve and extend access to Journal of Ecology 


\section{Transcaspian Vegetation}

growth forms described many excellent figures are given, showing habit and details of structure. Mention may be made of the annual Suaeda microsperma, which has the palisade tissue internal to the translucent water-storage tissue instead of surrounding it as is the more usual condition for halophytes. The roots of Aristida pennata have a casing of sand-grains, as described by Price ${ }^{1}$ in the case of $A$. pungens and other North African desert grasses.

The general features of the plants may be grouped under three heads. (1) A great difficulty attends the formation of long-lived shoots, even in trees the distal ends are lost. (2) Reduction of leaves or their complete suppression with an assimilating stem. (3) Frequency of the centric type of assimilating organ and of isobilateral leaves. These features of course do not occur in ephemerals and spring hemicryptophytes, which in many cases have no special xerophilous structures.

The concluding chapter deals with the elements composing the Transcaspian flora. A change of climate seems to have taken place with the emergence of the land from the sea which receded to the north and west. The new flora entering the area was exposed to very severe conditions. In the case of such a flora immigrant to a region of severe conditions from regions less rigorous, endemic species might be expected, and indeed the Transcaspian flora shows a very considerable percentage ( 22 per cent.) of endemic species. These generally follow the "spectrum," but there are no endemic marsh plants, more phanerophytes and hemicryptophytes, and fewer therophytes, than in the "spectrum." The smaller percentage of therophytes can be explained by such plants usually having a wide range of distribution and owing to their short vegetative season being able to flourish in very diverse habitats. Practically all the endemic species are closely allied to species of surrounding countries, so that it may be concluded that endemism in Transcaspia is geologically quite recent; there are no isolated forms which might be regarded as relicts. The other species show much more affinity with the southern than with the northern countries; very few species have a purely northern distribution from Transcaspia without occurring in the southern regions as well. This supports the view previously held by Engler that the immigration to Transcaspia was from the south and east, a conclusion which is fully borne out by Paulsen's analysis of the biological relations of the flora.

The author's method of treatment is admirable throughout, and presents a most vivid picture of the plants, both as individuals and grouped in vegetational units, in their struggles against very severe habitat conditions.

R. S. ADAMSON.

\section{MARINE ALGAL VEGETATION OF ICELAND}

\section{Jonsson, H. "The Marine Algal Vegetation of Iceland." Copenhagen} (J. Frimodt), 1912, 186 pp., 7 figures.

The present contribution forms the first instalment of The Botany of Iceland, edited by L. K. Rosenvinge and E. Warming, a work on the same lines as The Botany of the Faeroes and one which was taken in hand by the Danish botanists on the completion of that important publication. The author has already given an excellent systematic account of the Iceland algal flora, and three years ago he published in the Danish language a treatise on the vegetation. A detailed account in English from one so well acquainted with the area is therefore especially welcome.

After the systematic list with which the paper opens, the author describes the life conditions of the vegetation. This is followed by an account of the horizontal distribution of the species and the components of the flora, together with a comparison of neighbouring floral districts. The fifth chapter takes up the question of zones and the vertical distribution, after which comes the main section $(60$ pp.) which deals with the analysis and description of the marine algal vegetation.

The author avoids the use of the term "formation," and following Warming regards the marine vegetation as one subformation (Halonereid). For Kjellman's " regions" he employs the

1 Price, S. R. "The roots of some North African desert grasses." New Phytologist, 10, 1911, pp. $328-340$. 


\section{8}

Notuces of Work on Foreign Vegetation

term "zone," and divides the whole vegetation into littoral, semi-littoral and sub-littoral zones. In each of these he distinguishes a number of "associations," and where he thinks these are closely allied he links them together into "communities."

In the littoral zone he distinguishes two sets of associations which are designated (1) photophilous or strictly littoral communities and (2) the shade vegetation. The bulk of the algal growth comes under the first of these, while the Hildenbrandtia and Rhodochorton Rothii associations are examples of the second. The semi-littoral zone is a well-marked area, but to the reviewer the advisability of giving it equal rank to the littoral and sub-littoral zones appears doubtful. In Iceland, as in Britain, it is characterised specially by the presence of a number of small floridean (red algal) societies, many of which are more or less transient. The sub-littoral zone is very luxuriant, the five principal associations being those of the Laminariaceae, Desmarestia, deep-water Florideae, Lithothamnion, and crustaceous algae. The Zostera association is formed on a soft bottom, but is placed by itself as a community distinct from the algae.

On comparing this vegetation with that of the British Isles, one notes that floristically it differs considerably, and as a consequence the species composing the associations are often partly replaced by others. This is well seen in the case of the Laminariaceae and Fucaceae. In the former Fucus serratus is practically absent, its place being taken by a band of F. inflatus; while in the latter three additional species of Laminariaceae of large size materially alter the facies of the association.

The scheme of classification adopted by Jónsson adds another to the already numerous suggestions which have been put forward. Though some of the divisions in his valuable treatise may not commend themselves to algologists generally, there are others which are well worthy of consideration. It appears to the reviewer essential to distinguish in the first place the vegetation of rock, sand, and mud. This being done, the vertical distribution of each of these types may be studied, and Jónsson's substitution of "zone" for "region" is perhaps an improvement. But further subdivision is much more difficult. Additional work and wider experience will doubtless lead to the elimination of unsuitable subdivisions and bring about a certain measure of uniformity.

A. D. COTTON.

\section{PHYTOGEOGRAPHY OF NORWEGIAN MOSSES}

Hagen, J. “Geografiske grupper blant Norges lövmoser." Naturen (Kristiania), 1912 ; reprint of 22 pages.

In this useful and interesting paper, the author divides the mosses of Norway into the following phytogeographical groups-cosmopolitan, subarctic, arctic-alpine, southern, and western.

(1) The cosmopolitan species, while affording no clue as to their mode of immigration into Norway in particular, are of great general interest. For instance the fact that Polytrichum juniperinum occurs in all regions of the world shows that this species must have become specialised at a very early time-doubtless before Australia was isolated and while Africa and South America were still united by land. The author lays stress on the contention that the cosmopolitan mosses afford a clue to the geological age of this group.

(2) The great majority of the Norwegian mosses are subarctic species, and since these are widely distributed in the neighbouring countries to the east, it is concluded that they have entered Norway from this direction. Some of these forms have not yet reached the western Norwegian coast, while others (Splachnum luteum, S. rubrum, Dicranum elatum, D. fragilifolium, etc.) show their eastern origin clearly from their present distribution.

(3) Among the arctic-alpine mosses two groups may be distinguished-the purely circumpolar species and those which are also of alpine distribution; here are included certain species (Didymodon rufus, Desmatodon cernuus, Grimmia plagiopoda, etc.) which in Norway are restricted to the low-lying land north of the arctic circle.

(4) In the category of southern forms the author places those species which are most abundant in Central Europe; they require a warm summer, and therefore occur only in the 